\title{
Pemberdayaan Pemulung melalui Limbah Kardus
}

\author{
Purwani Puji Utami ${ }^{1 *}$, Niken Vioreza ${ }^{2}$, Arbiana Putri ${ }^{1}$ \\ ${ }^{1}$ pendidikan Pancasila dan Kewarganegaraan, STKIP Kusuma Negara \\ ${ }^{2}$ Pendidikan Guru Sekolah Dasar, STKIP Kusuma Negara \\ *purwani_puji@stkipkusumanegara.ac.id
}

\begin{abstract}
Abstrak
Pandemi virus Corona-19 menyebabkan kesulitan ekonomi. Kondisi ini juga dialami ribuan pemulung di Bantar Gebang, Kota Bekasi. Harga sampah terus menurun selama pandemi. Padahal, selain bisa dijual ke pabrik daur ulang, limbah plastik dan kardus juga dapat dimanfaatkan menjadi kerajinan tangan dengan nilai jual yang tinggi. Pengoptimalan usaha mikro limbah melalui pemberdayaan pemulung, dilakukan melalui jejaring Pusat Kegiatan Belajar Masyarakat (PKBM) Al Falah Sumur Batu dengan menyediakan layanan pendidikan gratis bagi para pemulung. Pelatihan keterampilan yang diberikan adalah pembuatan produk berbahan limbah. Untuk menghasilkan produk bernilai jual, pelatihan keterampilan diarahkan pada kualitas dan branding produk, diantaranya: (1) pelatihan desain produk, (2) pelatihan pembuatan produk, (3) branding kemasan produk, dan (4) pelatihan pemasaran online berbasis $e$-commerce, yang sangat sesuai dengan promosi produk di masa pandemi Covid-19. Pelatihan kewirausahaan ini memiliki tujuan sosial dan berbasis pada kegiatan sosial. Oleh sebab itu, pemulung juga diberikan penyuluhan motivasi kewirausahaan dan pelatihan keterampilan manajerial kewirausahaan. Selain itu dilakukan pendampingan kepada pemulung, agar upaya menumbuhkembangkan kegiatan usaha mikro pada para pemulung dapat terwujud dan berjalan dengan baik. Luaran dari kegiatan pengabdian ini adalah: (1) terbentuknya usaha mikro yang mampu memberikan penghasilan tambahan kepada pemulung, dan (2) terciptanya produk barang hasil produksi pemulung yang layak dipasarkan.
\end{abstract}

Kata kunci: daur ulang sampah, kerajinan tangan, limbah kardus, pemberdayaan, pemulung.

\section{PENDAHULUAN}

Usaha mikro, kecil dan menengah (UMKM) merupakan salah satu sektor di bidang ekonomi dalam sebuah negara, di Indonesia UMKM menjadi salah satu tulang punggung bagi beberapa masyarakat dalam meningkatkan kesejahteraan mereka, terbukti sektor UMKM dapat bertahan dalam situasi krisis ekonomi. Usaha kecil di Indonesia memainkan peranan penting dalam beberapa hal antara lain: (1) Usaha kecil merupakan pemain utama kegiatan ekonomi Indonesia, (2) Penyedia kesempatan kerja, (3) Pemain penting dalam pengembangan ekonomi lokal dan pengembangan masyarakat, (4) Pencipta pasar dan inovasi melalui fleksibilitas dan sensitivitasnya yang dinamis serta keterkaitannya dengan beberapa perusahaan, (5) Memberikan kontribusi terhadap peningkatan ekspor non migas (Utami, Vioreza, Nugraheny, Putri \& Arihati, 2019). Poin tersebut dapat didukung dengan keterampilan pengusaha dalam meningkatkan kinerja usahanya.

Indonesia merupakan salah satu Negara yang memiliki pertumbuhan UMKM yang sangat tinggi sebelum pandemi Covid-19 (Jayani, 2020), seperti yang tertera pada Gambar 1. Berdasarkan Gambar 1, dapat dikatakan bahwa perkembangan 
UMKM di Indonesia sebelum pandemi Covid-19 terus meningkat dari tahun ke tahun, hal tersebut yang menjadikan pemerintah Indonesia harus terus mendukung UMKM dengan memberikan bantuan baik dari segi modal maupun keterampilan pengusahanya. UMKM menyumbang 60,34\% (persen) dari total Produk Domestik Bruto (PDB) nasional dan menyumbang 58,18\% (persen) dari total investasi. Namun, UMKM juga menjadi kelompok yang rentan di tengah situasi pandemic Covid-19. Tak sedikit UMKM gulung tikar akibat badai ini Misalnya saja, warungwarung kecil yang terpaksa tutup karena sepi pembeli. Kamar Dagang dan Industri Indonesia (Kadin) mengonfirmasi dari 64.200.000 UMKM yang ada di Indonesia, sekitar 50\% (persen) atau setara 30.000.000 UMKM harus tutup sementara akibat pandemi Covid-19. Bahkan, berdasarkan data Lembaga Ilmu Pengetahuan Indonesia (LIPI), bila pandemi tak kunjung usai, 85,42 persen UMKM yang tidak berinovasi melalui pemasaran digital hanya akan mampu bertahan selama satu tahun (Farhanah, 2020).

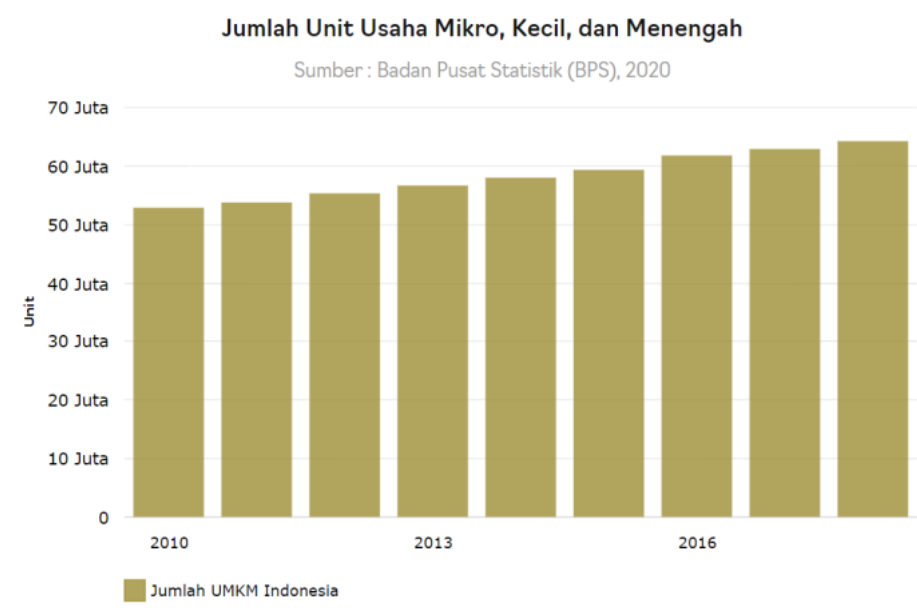

Gambar 1. Jumlah Unit Usaha Mikro, Kecil, dan Menengah

Berdasarkan data dari Kementerian Koperasi dan UMKM, hingga saat ini dari total 64.000.000 pelaku UMKM, baru sekitar 8.000.000 atau 13\% yang sudah terhubungan dengan dunia digital. Padahal, transaksi di dunia digital terus meningkat, terutama di masa pandemi ini, ketika pergerakan masyarakat mulai dibatasi. Dari data McKinsey yang disampaikan oleh Menteri Koperasi dan UMKM, Teten Masduki, sejak awal pandemi hingga Juni 2020 telah terjadi kenaikan penjualan melalui platform dagang-online sebesar $26 \%$ sehingga total transaksi mencapai 3.100.000 per hari (Waseso, 2020). Angka ini menunjukkan peluang yang besar bagi jutaan UMKM di Indonesia untuk memperluas jangkauan melalui digitalisasi. Namun, untuk mendukung percepatan transformasi digital para pelaku UMKM, dibutuhkan peran serta dari berbagai pihak, tidak cukup hanya pemerintah sendiri tetapi juga perlu dukungan dari pihak swasta dan masyarakat (Andriani, 2020).

Untuk mendukung pemanfaatan teknologi di sektor UMKM, Kementerian Koperasi dan UKM menargetkan tambahan 2.000.000 pelaku UMKM bisa Go digital hingga akhir 2020. Pemerintah melalui KEMENKOMINFO telah meminta kepada para pelaku UMKM untuk mulai beralih menjajakan produk mereka ke platform digital. Untuk bertahan di Era New Normal, UMKM perlu mempersiapkan sejumlah hal diantaranya, inovasi menjadi kunci beradaptasi. Dengan kreativitas 
dan gesit berinovasi, sebetulnya dalam berwirausaha bisa menciptakan peluang bisnis baru yang menguntungkan. Misalnya, inovasi dari sisi kanal penjualan, dari offline bersinergi dengan online, adopsi digital menjadi sangat vital. Atau juga, berinovasi dari sisi produk (Juminto, 2020).

UMKM ini ternyata juga bisa dikembangkan pada limbah yang oleh kebanyakan masyarakat dianggap tidak berguna, dengan menggunakan sedikit inovasi mengubah limbah menjadi barang unik dan bernilai ekonomis melalui pemasaran berbasis e-commerce. Selama ini kita mengetahui bahwa Tempat Pengelolaan Sampah Terpadu (TPST) berada di Bantar Gebang yang merupakan salah satu kecamatan di kota Bekasi, Provinsi Jawa Barat. Kecamatan ini terbagi menjadi 4 kelurahan, meliputi: Kelurahan Bantargebang 406,244 Ha; Kelurahan Cikiwul 525,351 Ha; Kelurahan Ciketing Udik 568,955 Ha; Kelurahan Sumur Batu 343,340 Ha.

Karakteristik mayoritas masyarakat Bantar Gebang berprofesi sebagai pemulung. Ditempat tersebut banyak sekali limbah sampah yang menjadi sandaran hidup bagi para pemulung mulai dari anak-anak, orang dewasa, hingga manula. Tidak berkembangnya kewirausahaan pada kalangan pemulung, bukan semata disebabkan keengganan karena keterampilan yang kurang sesuai dengan kebutuhan dan peminatan mereka, namun juga karena: (1) kepada mereka belum ditransformasikan motivasi kewirausahaan; (2) karena di dalam mind-set mereka, bahwa hanya ada satu pekerjaan yang dapat mereka lakukan yaitu sebagai pemulung, yang kesehariannya sangat bergantung pada pengumpulan limbah layak daur ulang. Dalam memenuhi kebutuhan hidup, masyarakat memiliki tingkat ketergantungan yang tinggi kepada tumpukan sampah. Bagi mereka berwirausaha bukan jalan hidupnya, karena sangat beresiko dan membutuhkan modal besar.

Padahal dari limbah plastik dan kardus selain dijual ke pabrik daur ulang, juga dapat dimanfaatkan kembali menjadi berbagai macam kerajinan tangan, baik itu hiasan dinding, perlengkapan rumah tangga, asesoris dan lainnya yang memiliki nilai jual lebih tinggi daripada di daur ulang (recycle). Hasil kerajinan tangan dengan sentuhan inovasi unik mampu memiliki nilai ekonomis yang "mahal". Melihat kondisi tersebut membuka peluang untuk mengadakan pemberdayaan masyarakat dalam memperbaiki ekonominya melalui pemanfaatan limbah sampah plastik dan kardus menjadi barang ekonomis yang bernilai jual tinggi.

Pengoptimalan usaha mikro limbah melalui pemberdayaan pemulung, dilakukan dengan menggunakan jejaring Pusat Kegiatan Belajar Masyarakat (PKBM) Al Falah Sumur Batu yang telah terorganisir secara baik, sebagai pusat pendidikan gratis bagi pemulung di Bantar Gebang.

Pelaksanaan kegiatan ini akan memberikan pelatihan keterampilan sesuai peminatan mitra serta sumber daya alam yang dimilikinya, agar nantinya mitra mampu menghasilkan produk unggulan yang memiliki nilai ekonomis serta dibutuhkan oleh pasar. Untuk menghasilkan produk yang memiliki nilai jual, pelatihan dari limbah kardus lebih diarahkan pada kualitas dan branding produk. Karena itu pelatihan yang diberikan juga akan mencakup teknis produksi dan desain produk serta branding kemasan produk. Materi keterampilan pembuatan produk kerajinan tangan yang diajarkan antara lain membuat pot bunga, tempat asesoris, pajangan yang berbahan dasar limbah kardus. Tak hanya itu, peserta juga diajarkan bagaimana mengemas produk kerajinan dengan teknik packaging yang dapat meningkatkan nilai jual, serta teknik pemasaran baik secara offline (langsung) 
maupun secara online berbasis e-commerce, seperti memiliki Website sendiri serta bekerjasama melalui digital mulai dari Gojek, Grab, Tokopedia, Bukalapak, Shopee, Blibli, dan Lazada sehingga program yang dijalankan dapat terintegrasi dengan ekosistem digital agar hasilnya lebih terukur serta memiliki akses pasar yang lebih luas.

Pelatihan kewirausahaan ini memiliki tujuan sosial dan berbasis pada kegiatan sosial. Oleh sebab itu, kepada mitra akan diberikan pula pelatihan motivasi kewirausahaan dan keterampilan manajerial kewirausahaan, yang didalamnya mencakup pula manajemen produksi, manajemen keuangan, akuntansi sederhana dan manajemen pemasaran. Selain itu dilakukan pendampingan kepada mitra, agar upaya menumbuhkembangkan kegiatan usaha mikro pada para pemulung dapat terwujud dan berjalan dengan baik. Luaran dari kegiatan pengabdian ini adalah: (1) Terbentuknya usaha mikro mitra yang mampu memberikan penghasilan tambahan kepada keluarga anggota mitra, dan (2) Terciptanya produk barang hasil produksi mitra yang layak dipasarkan.

\section{KAJIAN LITERATUR}

Analisis kelayakan usaha merupakan suatu analisis untuk mengetahui layak atau tidaknya usaha yang dijalankan dengan mengkaji beberapa aspek yaitu aspek teknis, pasar, manajemen, dan aspek finansial (Rangkuti, 2012). Oleh karena itu, analisis kelayakan usaha sangat perlu dilakukan untuk mengetahui apakah usaha kerajinan tangan yang dijalankan layak atau tidak layak, guna mencapai tujuan yakni memperoleh keuntungan atau laba optimal dan mengevaluasi keberlanjutan usaha.

Penelitian mengenai kelayakan usaha telah banyak dilakukan di beberapa lokasi dengan obyek usaha yang berbeda (Tangke, 2011; Latuny, 2010; Jafar \& Kasmir, 2010; Palupi, Ira \& Asriyana, 2016; Umar, 2003), namun kelayakan usaha kerajinan limbah sampah belum dilakukan. Hal tersebut menjadi dasar pertimbangan sehingga diperlukan kajian mengenai kelayakan finansial usaha kerajinan tangan/souvenir dari limbah oleh pelaku usaha yaitu pemulung di Bantar Gebang.

\section{METODE PELAKSANAAN}

Munculnya usaha mikro menandai perlunya dorongan perubahan sosial dalam masyarakat untuk menghasilkan transformasi bermanfaat yang berkelanjutan. Sehingga munculnya usaha mikro penting sebagai jalan keluar masyarakat sendiri, dan bukan mengandalkan langkah dari pemerintah (Listyorini, 2012). Konsep usaha mikro dalam hal ini diartikan sebagai sebuah usaha bisnis yang dicipta untuk tujuan sosial, mengatasi atau mengurangi masalah sosial dan masalah kegagalan pasar, dan untuk mendorong nilai sosial sambil tetap beroperasi secara disiplin keuangan, inovasi dan taktik-taktik sektor usaha dan kegiatan bisnis tersebut dibangun bertolak dari kegiatan-kegiatan sosial (Listyorini, 2012).

Responden dalam kegiatan ini adalah masyarakat yang berprofesi sebagai pemulung di Kelurahan Sumur Batu, Kecamatan Bantar Gebang, Kota Bekasi. Terdapat 20 pemulung yang menjadi sasaran kegiatan ini.

Target luaran kegiatan pengabdian ini adalah dihasilkannya produk baru yang merupakan pengembangan varian produk usaha berupa: (1) vas bunga, tempat 
asesoris, pajangan, dan lain-lain; (2) sistem manajemen usaha yang efektif yang meliputi pembukuan, laporan keuangan, personalia, (3) sistem pemasaran berbasis web, dan (4) artikel ilmiah dalam jurnal. Karena khalayak sasaran dalam kegiatan ini adalah para pemulung, sehingga pengabdian ini bekerjasama dengan PKBM yang segala aktivitasnya sudah melembaga dalam kehidupan sehari-hari pemulung Kelurahan Sumur Batu, hal ini merupakan modal social yang didalamnya terjalin: jejaring, kepercayaan, gotong royong dan nilai-nilai kehidupan lainnya. Pendayagunaan modal sosial tersebut dapat menjadi media pemberdayaan masyarakat dan penciptaan lapangan kerja (Thobias, Tungka \& Rogahang, 2013).

Berpijak pada konsep di atas, dan sebagaimana permasalahan, kebutuhan mitra serta kondisi dan karakter mitra, yang hendak dilakukan adalah meningkatkan pendapatan keluarga melalui peningkatan keterampilan dan kapasitas produksi mitra untuk menghasilkan produk-produk bernilai ekonomis, yang dibangun dari kelembagaan dan kegiatan sosialnya. Kepada para pemulung mitra akan diberikan pelatihan dan pendampingan kegiatan yang dilakukan meliputi penyuluhan dan pelatihan dengan metode ceramah, diskusi, tanya jawab dan demonstrasi.

\section{Tahap Persiapan dan Perencanaan}

Tahap persiapan dan perencanaan dilakukan koordinasi dengan dengan LPPM STKIP Kusuma Negara.Tim pelaksana kegiatan dalam hal ini mempersiapkan alat dan bahan yang diperlukan untuk pembuatan aksesoris, dan pemantauan kegiatan.

\section{Tahap Pelaksanaan Produk}

Tahap Pelaksanaan Produk, yang meliputi: (a) memberikan penyuluhan tentang menghasilkan kreasi kerajinan tangan yang berkualitas yang mampu mengembangkan secara luas; (b) memberikan inovasi kerajinan tangan yang ramah lingkungan untuk mendukung kebersihan dan kenyamanan lingkungan sekitar; (c) memberikan penyuluhan menjadikan kerajinan tangan sebagai bisnis yang siap menghadapi pesaing pasar dengan kerajinan modern; (d) memberikan penyuluhan menjadikan kerajinan sebagai bisnis dalam negeri dan bisa dijual sampai keluar negeri melalui pemasaran berbasis online.

\section{Pelatihan Keterampilan Pembuatan Kerajinan dari Limbah Kardus}

Pembuatan produk dari bahan limbah kardus yang didahului dengan perencanaan disain produk, membuat pola sesuai dengan ukuran dan disain produk, mengkombinasikan bahan baku dengan bahan dekoratif lainnya sesuai dengan disain. Setelah itu kardus dibentuk berbagai jenis bunga, daun dan bentuk lainnya, maka seluruhnya disusun sehingga menjadi produk pajangan, dan juga mengemas produk.

Diarahkan untuk menciptakan produk yang memiliki nilai jual tinggi dan sebagai produk unggulan mitra, pelatihan ini akan mencakup: (a) pelatihan desain produk; (b) pelatihan pembuatan produk; (c) branding kemasan produk; (d) pelatihan pemasaran online berbasis e-commerce.

Alat yang dibutuhkan: (a) gunting, (b) cutter, (c) lem tembak atau glue gun, (d) penggaris, (e) kuas untuk melukis, (f) hot glue gun size $12 \mathrm{~mm}$, (g) mesin jigsaw. Bahan yang dibutuhkan: (a) limbah kardus, (b) lilin lem tembak/hot melt glue, (c) lidi, (d) cat poster isi 12 warna. Alat dan bahan dapat dilihat seperti Gambar 2. 

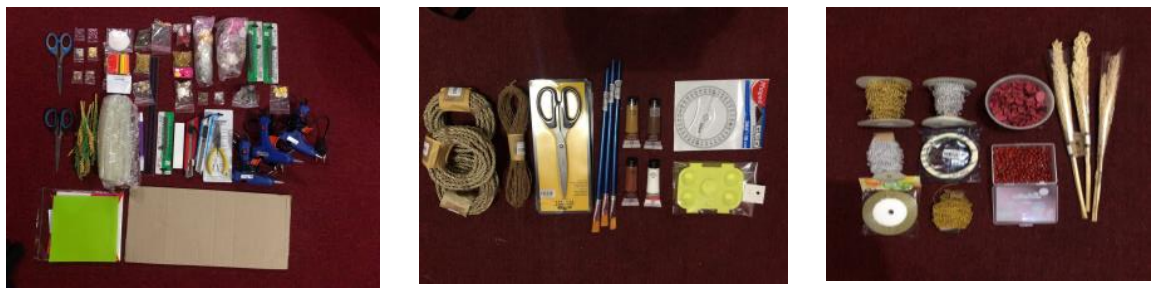

Gambar 2. Alat dan Bahan untuk Pelatihan

Tahapan pembuatan hiasan bunga dari limbah kardus: (a) siapkan limbah kardus dan potong ukuran $40 \times 30 \mathrm{~cm}$ untuk dijadikan latar belakang hiasan bunga; (b) cat satu sisi kardus dengan cat poster; (c) potong kardus bentuk oval dengan berbagai ukuran untuk dirangkai menjadi bunga dan daun (Gambar 3a); (d) kelupas lapisan luar kardus sehingga menampilkan motif gelombang kardus yang akan dijadikan sebagai bentuk bunga (Gambar 3b); (e) sisa lapisan luar digunting oval untuk nanti dijadikan daun, dengan cara diserut lembut di bagian ujungnya (Gambar 3c); (f) buat bentuk atau pola bunga dengan kardus bergelombang tadi beberapa buah, pisahkan (Gambar 3d); (g) potong kardus dengan bentuk segitiga untuk dijadikan sebagai pot dan tempelkan pada background yang sudah dicat tadi dengan sisi atas tidak di lem; (h) ambil sebilah lidi, tempelkan sisa lapisan kardus tipis sebagai daunnya, lalu gabungkan dengan bunga di ujung atasnya dengan lem (Gambar 3e); (i) susun tangkai-tangkai bunga pada pot yang sudah ditempel pada background; (j) rapikan sisa lem disekitar bunga; (k) hiasan dinding bunga limbah kardus siap digunakan (Gambar 3f).
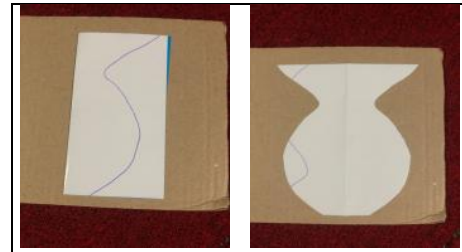

(a)

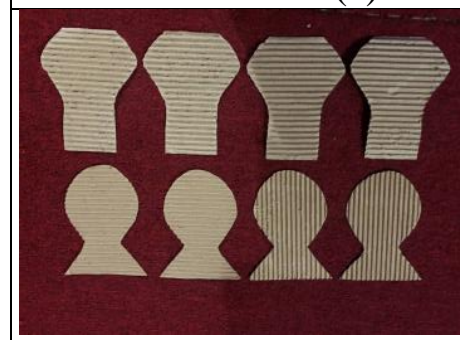

(d)
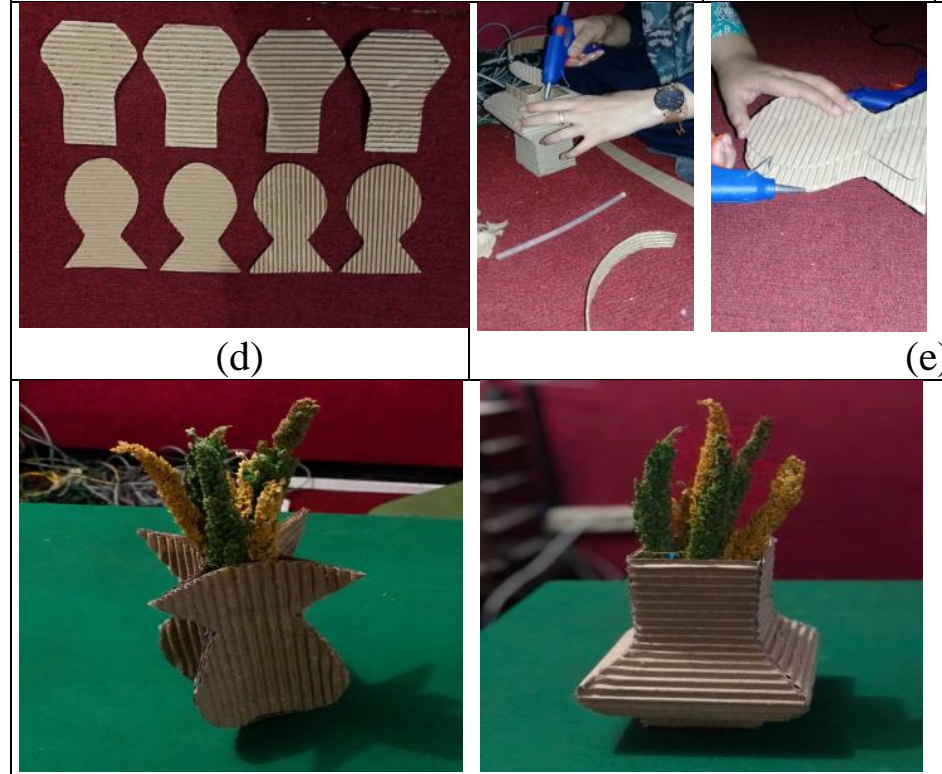

(f)

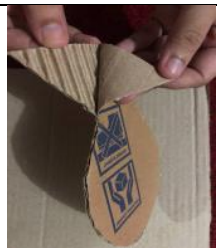

(b)

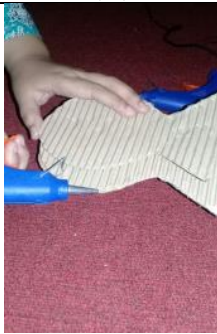

(e)
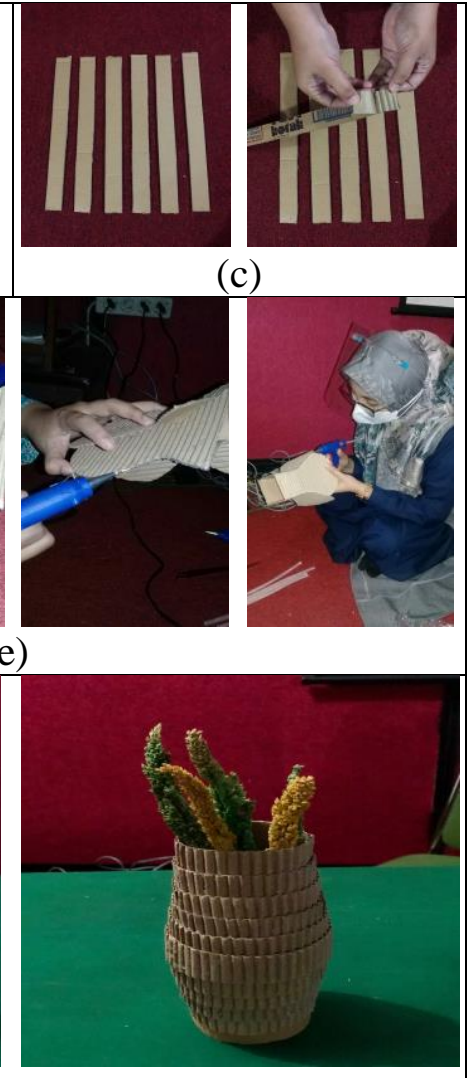

Gambar 3. Beberapa Tahapan Pembuatan Hiasan Bunga dari Limbah Kardus 
Berikut dokumentasi kegiatan pelatihan pembuatan produk.
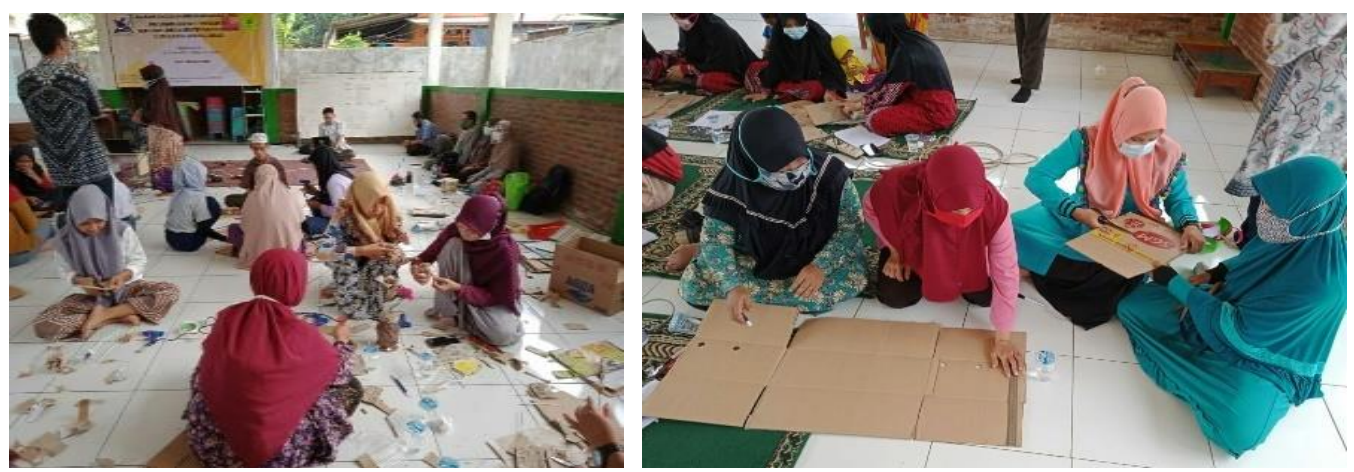

Gambar 4. Dokumentasi Kegiatan Pelatihan Pembuatan Kerajinan

\section{Pelatihan Motivasi dan Skill Manajerial}

Penyuluhan motivasi wirausaha dan pelatihan skill manajerial kewirausahaan, diarahkan untuk menumbuhkan motivasi peserta dalam berwirausaha dan kemampuan mengelola usaha, pelaksanaannya seperti pada Gambar 5, yang meliputi: (a) penyuluhan motivasi usaha; (b) pengenalan usaha mikro; (c) pelatihan pembuatan perencanaan usaha; (d) pelatihan manajemen operasi dan produksi; (e) pelatihan manajemen pemasaran; dan (f) pelatihan manajemen keuangan dan akuntansi sederhana.
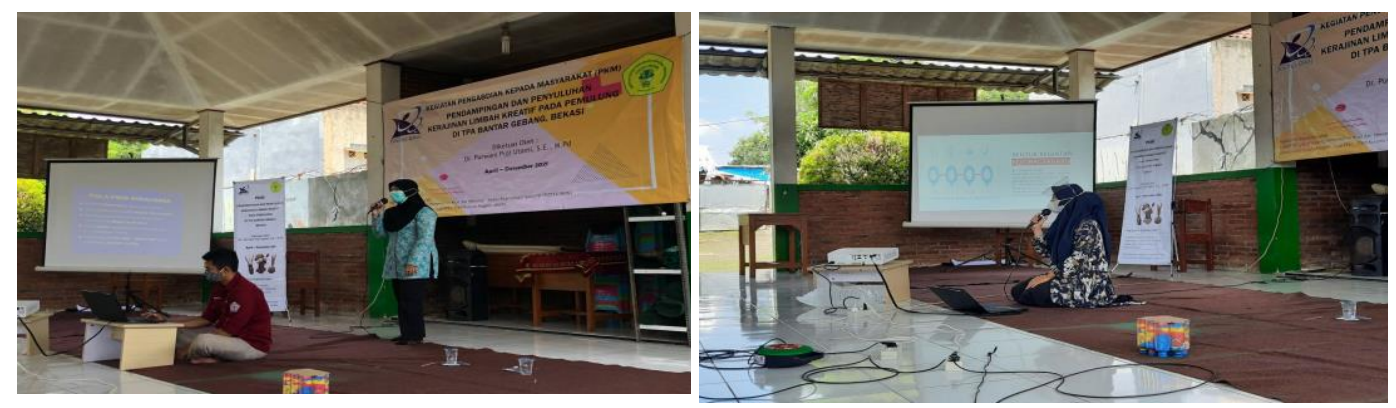

Gambar 5. Dokumentasi Pelatihan Motivasi dan Skill Manajerial

\section{Pelatihan Pemanfaatan TIK untuk Pemasaran}

Pelatihan pemanfaatan e-commerce untuk pemasaran, diarahkan untuk menumbuhkan pengetahuan dan pemahaman kemudahan dalam pemasaran dengan menggunakan TIK, pelaksanaannya seperti pada Gambar 6, yang mencakup: (a) pengenalan TIK dan jejaring media sosial internet; (b) pembuatan blog; (c) pemanfaatan TIK untuk pemasaran secara online; (d) transaksi dalam pemasaran online.

\section{Pendampingan kepada Para Peserta Pelatihan}

Kegiatan ini dalam rangka menambah pengetahuan: (a) pemahaman dan aplikasi pengetahuan dan skill manajerial; (b) analisis potensi pasar dan pembuatan perencanaan usaha dan agar aplikatif; (c) merancang/membangun dan mengelola usaha bersama dalam bentuk usaha mikro melalui kegiatan PKBM (mulai dari perencanaan, proses produksi, pemasaran, pengaturan mekanisme dan sistem pembagian keuntungan usaha). 


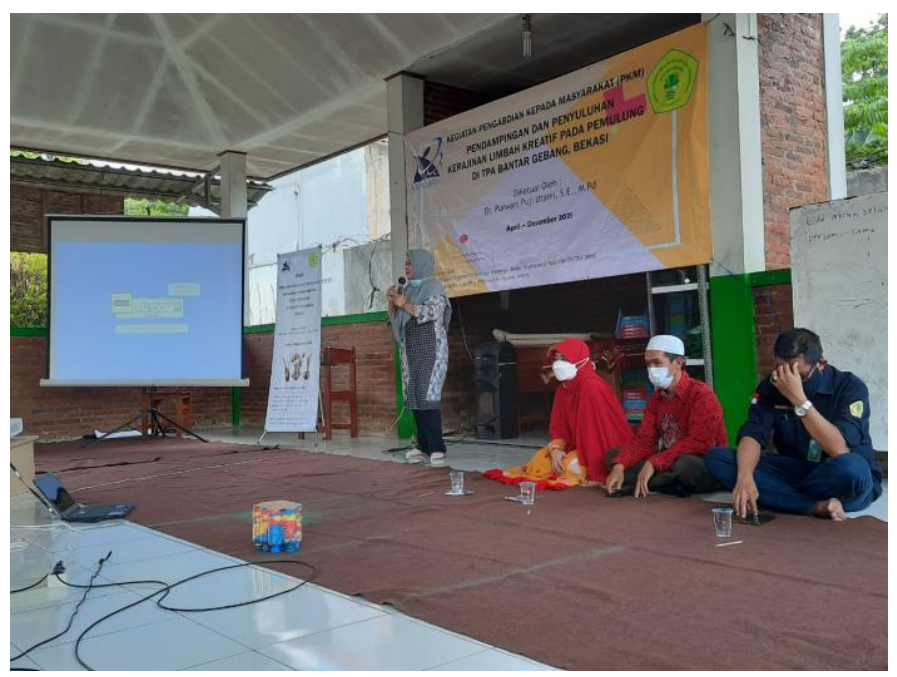

Gambar 6. Dokumentasi Pelatihan Pemanfaatan TIK

\section{HASIL DAN PEMBAHASAN}

Pelaksanaan pengabdian ini untuk mendukung upaya pengoptimalan usaha mikro pada pemulung. Target yang dicapai adalah: (1) tumbuh-kembangnya motivasi kewirausahaan; (2) tumbuh-kembangnya keterampilan dan kegiatan para pemulung mitra yang mampu menghasilkan produk yang memiliki nilai ekonomis; (3) tumbuh-kembangnya keterampilan manajerial kewirausahaan dan pemasaran berbasis e-commerce; (4) tumbuh-kembangnya kegiatan wirausaha para pemulung mitra, melalui pendampingan dan pembinaan dari kegiatan pengabdian.

Luaran yang dicapai melalui kegiatan pengabdian ini adalah peningkatan kesejahteraan keluarga para pemulung mitra, agar semakin berdaya dan semakin meningkat perekonomiannya melalui: (1) terbentuknya usaha mikro mitra yang mampu memberikan penghasilan tambahan kepada keluarga anggota mitra; (2) terciptanya produk barang mitra yang layak dipasarkan. Berikut contoh-contoh hasil kerajinan limbah kardus seperti pada Gambar 7.

Pada pelatihan manajerial, para pemulung memperoleh manfaat mampu melakukan analisis perhitungan BEP untuk mengetahui gambaran kondisi produksi yang harus dicapai untuk melampaui titik impas. Kegiatan wirausaha dikatakan impas jika jumlah hasil penjualan produknya pada suatu periode tertentu sama dengan jumlah biaya yang ditanggung sehingga usaha tersebut tidak menderita kerugian, tetapi juga tidak memperoleh laba. Analisis titik impas dapat disebut Break Event Point (BEP) dimana dapat diperhitungkan batas kuantitas produksi yang mengalami keuntungan dan kerugian pada usaha yang dilakukan oleh pemulung. Analisis kelayakan usaha atau disebut juga feasibility study adalah kegiatan untuk menilai sejauh mana manfaat yang dapat diperoleh dalam melaksanakan suatu kegiatan usaha. Hasil analisis ini digunakan sebagai bahan pertimbangan dalam mengambil keputusan, apakah menerima atau menolak dari suatu gagasan usaha. Pengertian layak dalam penelitan ini adalah kemungkinan dari gagasan suatu usaha yang akan dilaksanakan dapat memberikan manfaat dalam arti finansial maupun social benefit. Dengan adanya analisis kelayakan diharapkan resiko kegagalan dalam usaha produktif dapat dihindari (Jafar \& Kasmir, 2010). 

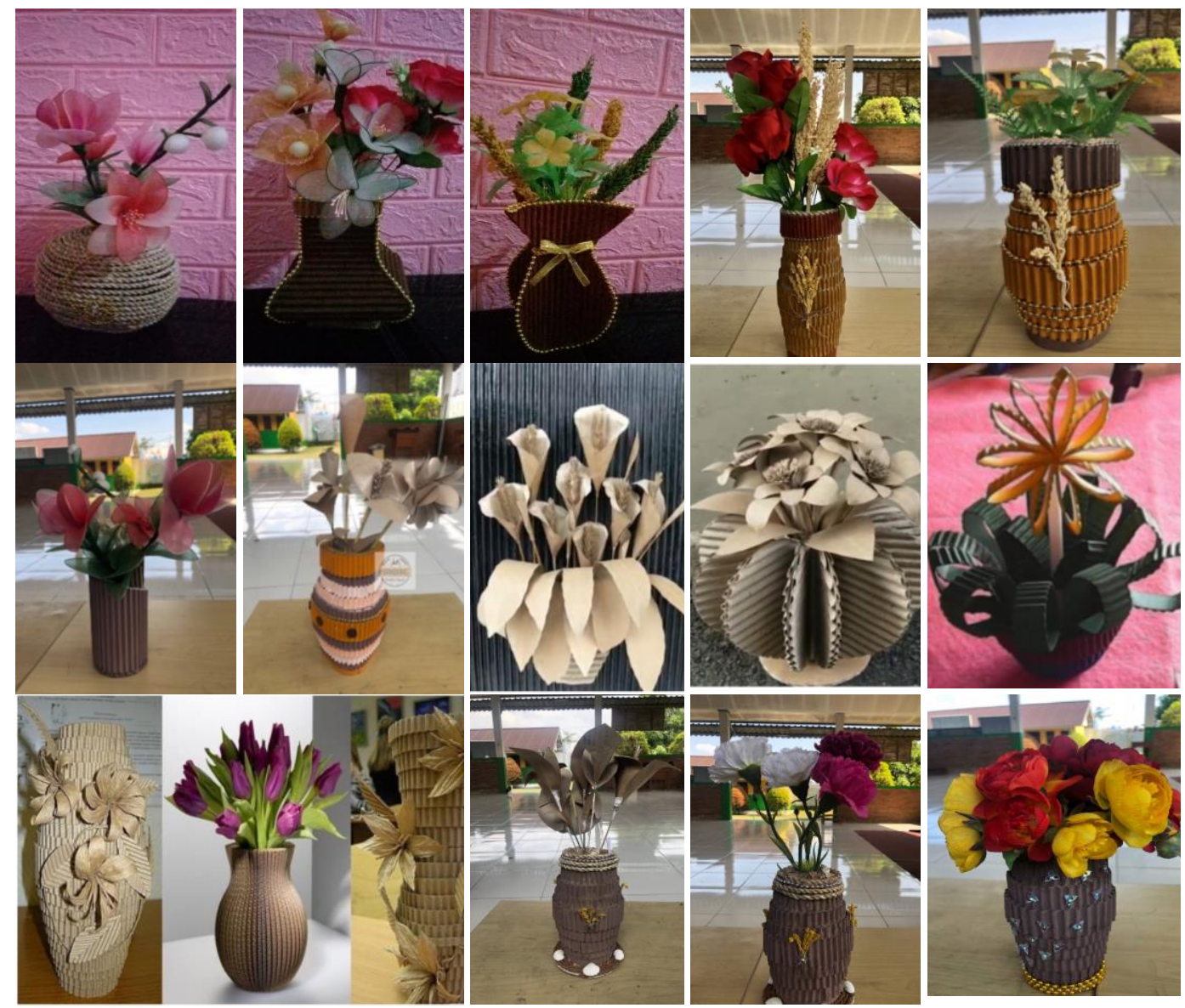

Gambar 7. Contoh Hasil Kerajinan

\section{UCAPAN TERIMA KASIH}

Penulis mengucapkan terimakasih kepada Kementerian Riset dan Teknologi-Badan Riset Inovasi (RISTEK-BRIN) dan LLDIKTI Wilayah III Jakarta yang telah memberi hibah untuk kegiatan Pengabdian kepada Masyarakat, dan kami haturkan ucapan terimakasih kepada Ketua STKIP Kusuma Negara, Kaprodi PPKN STKIP Kusuma Negara, Kepala Sekolah PKBM Al-Falah Sumur Batu, Ketua RT.002/RW.001 Kelurahan Sumur Batu Kecamatan Bantar Gebang, serta semua pihak yang berperan sehingga terlaksana kegiatan PKM pendampingan dan penyuluhan kerajinan limbah kreatif pada pemulung di TPA Bantar Gebang Bekasi, sehingga dapat dituangkan dalam bentuk tulisan dan di informasikan pada artikel.

\section{SIMPULAN}

Pelatihan kewirausahaan ini memiliki tujuan sosial dan berbasis pada kegiatan sosial. Oleh sebab itu, kepada mitra diberikan pula pelatihan motivasi kewirausahaan dan keterampilan manajerial kewirausahaan, yang didalamnya mencakup pula manajemen produksi, manajemen keuangan, akuntansi sederhana dan manajemen pemasaran (pemasaran offline dan online melalui pelatihan TIK), agar kegiatan kewirausahaan yang dibina dapat berkembang sesuai dengan tujuan 
pengabdian. Selain itu dilakukan pendampingan kepada mitra, dalam menumbuhkembangkan kegiatan usaha mikro sehingga dapat terwujud dan berjalan dengan baik.

Melalui kegiatan pemberdayaan berbasis masyarakat seperti ini dapat memanfaatkan limbah di dalam pengelolaan lingkungan hidup, kegiatan ini juga dapat meningkatkan kualitas masyarakat daerah binaan. Peserta juga didorong untuk terus meningkatkan kreativitas dalam rangka menciptakan kemandirian serta meningkatkan perekonomian masyarakat, sehingga pencapaian Goals No Poverty dalam Sustainable Development Goals (SDGs) dapat segera terwujud. Mengingat pemulung, yang menjadi peserta kegiatan, selama ini masih digolongkan ke dalam kaum marginal, yang juga merupakan salah satu masyarakat terdampak pandemi Covid-19 di tanah air.

\section{DAFTAR PUSTAKA}

Andriani, D. (2020). UMKM Didorong Adaptasi di Masa Pandemi, Go Digital!. Bisnis. Com [HTM file]. Tersedia: https://ekonomi.bisnis.com/read/20200908/ 12/1288568/umkm-didorong-adaptasi-di-masa-pandemi-go-digital

Farhanah. (2020). UMKM Terdampak Pandemi, Pemerintah dan Swasta Gotong Royong Dorong Pertumbuhan Ekonomi. Kompas. Com [HTM file]. Tersedia: https://money.kompas.com/read/2020/09/09/143611226/umkmterdampak-pandemi-pemerintah-dan-swasta-gotong-royong-dorongpertumbuhan

Jafar \& Kasmir. (2010). Studi Kelayakan Bisnis. Jakarta: Kencana Prenada Media Group.

Jayani, D. H. (2020). Pemerintah Beri Stimulus, Berapa Jumlah UMKM di Indonesia?. Fitra, S. (Ed.). Badan Pusat Statistik (BPS) Online [HTM file]. Tersedia: https://databoks.katadata.co.id/datapublish/2020/04/08/pemerintahberi-stimulus-berapa-jumlah-umkm-di-indonesia

Juminto, M. S. (2020). Adaptasi UMKM saat New Normal [HTM file]. Tersedia: https://www.jawapos.com/opini/24/06/2020/adaptasi-umkm-saat-new-normal/

Latuny, W. (2010). Analisis kelayakan aspek finansial industri kerajinan kerang mutiara (Studi kasus pada UD. Mutiara Indah). Arika, 4(1), 89-96.

Listyorini, H. (2012). Komponen dan Dampak Sosial Entrepreneurship Dalam Upaya Revitalisasi Budaya dan Industri Batik Lasem, Kabupaten Rembang. Jurnal Dinamika Kepariwisataan, 11(2), 48-57.

Palupi, R. D., Ira, I., \& Asriyana, A. (2016). Strategi Pengembangan Usaha Wanita Nelayan dalam Mengolah Hasil Perikanan Berbasis Kelompok. Jurnal Bisnis Perikanan (Journal of Fishery Business), 3(2), 137-144.

Rangkuti, F. (2012). Studi Kelayakan Bisnis \& Investasi. Jakarta: Gramedia Pustaka Utama.

Tangke, U. (2011). Analisis kelayakan usaha perikanan tangkap menggunakan alat tangkap gill net dan purse seine di Kecamatan Leihitu Kabupaten Maluku Tengah Provinsi Maluku. Agrikan: Jurnal Agribisnis Perikanan, 4(1), 1-13.

Thobias, E., Tungka, A. K., \& Rogahang, J. J. (2013). Pengaruh modal sosial terhadap perilaku kewirausahaan (suatu studi pada pelaku usaha mikro kecil menengah di Kecamatan Kabaruan Kabupaten Kepulauan Talaud). Acta Diurna Komunikasi, 2(2), 1-12. 
Umar, H. (2003). Studi Kelayakan dalam Bisnis Jasa. Jakarta: Gramedia Pustaka Utama.

Utami, P. P., Vioreza, N., Nugraheny, D. C., Putri, A., \& Arihati, D. B. (2019). PkM Kelompok UMKM Kerajinan Tangan Unik Laut. Jurnal Abadimas Adi Buana, 3(1), 49-56.

Waseso, R. (2020). Penjualan meningkat 26\% sejak pandemi, UMKM didorong masuk pasar e-commerce. Laoli, N. (Ed.). Kontan.co.id Online [HTM file]. Tersedia: https://nasional.kontan.co.id/news/penjualan-meningkat-26-sejakpandemi-umkm-didorong-masuk-pasar-e-commerce 